\title{
The inhibitory effects of cisplatin-radiation combination treatment on malignant osteosarcoma MG-63 cells and BRCA1-p53 pathways are more efficient than single treatments
}

\author{
HONG-BIN SUN ${ }^{1 *}$, HE-YUAN WANG ${ }^{2 *}$, BING WU $^{3}$, ZHONG-FENG WANG $^{4}$, \\ LI-ZHE WANG $^{5}$, FU-QIANG LI ${ }^{6}$, JUN-DUO $\mathrm{WU}^{7}$ and LE-NING ZHANG ${ }^{1}$ \\ ${ }^{1}$ Department of Thoracic Surgery, China-Japan Union Hospital of Jilin University, Changchun, Jilin 130033; \\ ${ }^{2}$ Department of Endocrinology and Metabolism, The First Hospital of Jilin University, Changchun, Jilin 130021; \\ ${ }^{3}$ Department of Neurosurgery, China-Japan Union Hospital of Jilin University, Changchun, Jilin 130033; \\ Departments of ${ }^{4}$ Hepatology and ${ }^{5}$ Pediatric Oncology, The First Hospital of Jilin University, Changchun, Jilin 130021; \\ ${ }^{6}$ Eye Center of The Second Hospital of Jilin University; ${ }^{7}$ Department of Cardiology, \\ The Second Hospital of Jilin University, Changchun, Jilin 130041, P.R. China
}

Received June 13, 2018; Accepted August 22, 2019

DOI: $10.3892 / \mathrm{ol} .2019 .11019$

\begin{abstract}
The poor prognosis of patients with osteosarcoma remains a persistent problem, in particular for patients with unresectable tumors or metastasis. Therefore, combination of radiotherapy and chemotherapy has been considered for patients with metastasis or recurrence, patients unsuitable for surgery and patients refusing surgery. The present study aimed to investigate the effect of the combined treatment with cisplatin and radiation therapy on the biological characteristics of the osteosarcoma cell line MG-63 and the breast cancer 1 (BRCA1)-associated signaling pathways. Cell proliferation was determined using Cell Counting kit- 8 assay, and cell apoptosis and cell cycle were assessed by flow cytometry. Cell migration was examined by Transwell assay. The mRNA and protein expression levels of candidate genes, including BRCA1 and p53, were determined by reverse transcription-quantitative PCR and western blotting, respectively. The results demonstrated that combined treatment with radiation and cisplatin significantly inhibited MG-63 cell proliferation compared with radiation or cisplatin treatment alone. Furthermore, radiation, cisplatin or the combined treatment with radiation and cisplatin increased the apoptosis rate of MG-63 cells, which resulted in $G_{2}$ phase arrest, and significantly decreased the migratory capacity of MG-63 cells. In addition, the apoptosis rate of MG-63 cells following combined radiation and cisplatin treatment was
\end{abstract}

Correspondence to: Dr Le-Ning Zhang, Department of Thoracic Surgery, China-Japan Union Hospital of Jilin University, 126 Xiantai Street, Changchun, Jilin 130033, P.R. China

E-mail: 951446482@qq.com

*Contributed equally

Key words: combined cisplatin-radiation, cisplatin, radiation, osteosarcoma, MG-63 cell line, BRCA1-p53 pathway higher compared with the cisplatin group, but lower compared with the radiation group. Furthermore, combined treatment with radiation and cisplatin decreased the mRNA and protein expression levels of BRCA1 and p53. Additionally, combined treatment with radiation and cisplatin had a more potent inhibitory effect on p53 expression than on BRCA1 expression. In addition, combination of radiation and cisplatin had a higher inhibitory effect on Bax protein level and a higher inductive effect on Bcl-2 protein level compared with treatments with radiation and cisplatin alone. The results demonstrated that combined treatment of radiation and cisplatin exhibited superior therapeutic effects on osteosarcoma MG-63 cells compared with radiation or cisplatin treatment alone, which may be mediated by the BRCA1-p53 signaling pathway.

\section{Introduction}

Osteosarcoma is a malignant bone tumor that occurs in children and young people with an incidence of 2-5 per million and in older adults with an incidence of $1.5-5$ per million $(1,2)$. The incidence rate and occurrence age of osteosarcoma in children and young people is relatively stable with little geographic variation, whereas they vary in older patients $(1,2)$. The treatment strategy of osteosarcoma is commonly based on surgical resection combined with systemic chemotherapy, including neoadjuvant chemotherapy, followed by restoration of limb function (3-5). In addition, the five-year overall survival rate of patients with osteosarcoma has significantly increased from $<30$ to $>70 \%$, which may be due to the use of neoadjuvant chemotherapy (6).

The use of chemotherapy for patients with osteosarcoma consists of adjuvant and neoadjuvant chemotherapy, including doxorubicin, cisplatin, methotrexate or cyclophosphamide (7-9). Chemotherapy induces tumor necrosis, promotes surgical resection and inhibits micrometastasis (10-14). However, drug resistance reduces the effect of chemotherapy $(15,16)$. Refining the chemotherapy regimen to improve the prognosis in patients with osteosarcoma remains challenging for scientists $(15,16)$. 
Radiotherapy is an adjuvant treatment for osteosarcoma that can inhibit tumor cell activity, reduce the local recurrence rate and prolong the overall survival of patients with osteosarcoma (17-20). Radiotherapy can be offered to patients with inoperable tumors or patients who cannot tolerate chemotherapy $(14,21,22)$.

The poor prognosis of patients with osteosarcoma has remained a persistent problem in the last decades, in particular for patients with inoperable tumors or metastasis, even when chemotherapy duration is prolonged, the dose is increased, or an immune treatment is adopted (6). Considering the young age of patients with osteosarcoma, the malignant nature of osteosarcoma, the absence of one single specific therapeutic method, the significant side effects and poor overall effects, it is crucial to develop a novel and effective therapy with low toxic effects to treat patients with osteosarcoma (23).

Engert et al (24) reported the presence of the BRCAness phenomenon in osteosarcoma and demonstrated that poly (ADP-ribose) polymerase inhibitors targeting breast cancer $1 / 2$ (BRCA1/2) mutations in patients with breast cancer can also inhibit osteosarcoma cell proliferation, which suggests that the BRCA gene could be associated with the occurrence and development of osteosarcoma (24-27).

At present, the combination of neoadjuvant chemotherapy and surgery remains the first-line treatment applied to patients with osteosarcoma. The combination of radiotherapy and chemotherapy has been used for patients with metastasis or recurrence, patients unsuitable for surgery and patients refusing surgery $(14,28)$. Furthermore, it has been demonstrated that the combined use of radiotherapy and chemotherapy can benefit the survival of patients with osteosarcoma and increase the rate of limb salvage (29). The present study investigated the effect of the combined radiation and cisplatin treatment on the malignant osteosarcoma cell line MG-63 and the BRCA1-associated signaling pathways. The findings from the present study may provide a basis for the clinical application of radiation and cisplatin therapy for osteosarcoma.

\section{Materials and methods}

Cell line and reagents. The MG-63 osteosarcoma cell line was purchased from The Cell Bank of Type Culture Collection of the Chinese Academy of Sciences. The bicinchoninic acid (BCA) protein assay kit was purchased from Beijing Biomedical Co., Ltd. PVDF membranes were purchased from EMD Millipore. Skimmed milk powder was purchased from Sangon Biotech (Shanghai) Co., Ltd.

Cell culture and determination of cell proliferation. The osteosarcoma cell line MG-63 was cultured in H-Dulbecco's Modified Eagle medium (Gibco; Thermo Fisher Scientific, Inc.) containing 10\% FBS (Biological lndustries) and 1\% antibiotics penicillin and streptomycin (Beijing Solarbio Science $\&$ Technology Co., Ltd.) and placed at $37^{\circ} \mathrm{C}$ in a humidified incubator containing $5 \% \mathrm{CO}_{2}$. Cells $\left(2 \times 10^{3} /\right.$ well in $\left.100 \mu \mathrm{l}\right)$ in the logarithmic growth stage were seeded in a 96-well plate and cultured overnight. Cells were then treated by radiation $(0,0.5,1,1.5$ and $2 \mathrm{~Gy})$ and/or cisplatin $(0,5,10,20$ and $40 \mu \mathrm{g} / \mathrm{ml}$ ) at $37^{\circ} \mathrm{C}$ for $24 \mathrm{~h}$. For combined treatment, radiation was applied first and followed by cisplatin treatment. Following
$12 \mathrm{~h}$ culture, cell proliferation was determined using a Cell Counting Kit-8 (CCK-8; 7seaPharm Technology, Co. Ltd.) according to the manufacturer's protocol. The absorbance was measured at $450 \mathrm{~nm}$ with a microplate reader.

Determination of cell apoptosis. MG-63 cells in the logarithmic growth stage were seeded in a 6 -well plate at a density of $2 \times 10^{5} / 2 \mathrm{ml} /$ well and cultured overnight. Cells were treated by radiation and/or cisplatin as aforementioned. Following $12 \mathrm{~h}$ culture, cells were collected, and apoptosis was determined using Annexin V/propidium iodide (PI) (BD Biosciences; cat. no. 559763) according to the manufacturer's instructions. Briefly, cells were washed twice with cold PBS and resuspended in 1X Binding Buffer (BD Biosciences; cat. no. 51-66121E) at the concentration of $1 \times 10^{6}$ cells $/ \mathrm{ml}$. The cell suspension (100 $\mu \mathrm{l}, 1 \times 10^{5}$ cells) was transferred into a $5 \mathrm{ml}$ culture tube. Annexin V-PE (5 $\mu \mathrm{l}$; BD Biosciences; cat. no. 51-65875X) and $5 \mu 1$ 7-Amino-actinomycin D (BD Biosciences; cat. no. 51-68981E) were added. The solution was gently mixed and incubated for $15 \mathrm{~min}$ at room temperature in the dark. Binding Buffer $(400 \mu \mathrm{l})$ was added to each tube. Cells were analyzed by flow cytometry within $1 \mathrm{~h}$. The results were analyzed using CytExpert 1.2 software (Beckman Coulter, Inc.).

Determination of cell cycle. MG-63 cells in the logarithmic growth stage were seeded in a 6-well plate at a density of $2 \times 10^{5} / 2 \mathrm{ml} /$ well and cultured overnight. Cells were treated by radiation and/or cisplatin as aforementioned. Following $12 \mathrm{~h}$ culture, cells were collected in $500 \mu \mathrm{l}$ of $0.1 \%$ Triton X-100 PBS buffer containing $12.5 \mu \mathrm{l}$ PI and $10 \mu \mathrm{l}$ RNase A and incubated in a $\mathrm{CO}_{2}$ incubator at $37^{\circ} \mathrm{C}$ for $30 \mathrm{~min}$. Cell cycle distribution was determined using an EPICS-XL flow cytometer (Beckman Coulter, Inc.). The results were analyzed using CytExpert 1.2 software.

Examination of cell migration. MG-63 cells in the logarithmic growth stage were seeded in a 24 -well Transwell (pore size, $8 \mu \mathrm{m}$ ) insert at a density of $5 \times 10^{3} / 200 \mu \mathrm{l} /$ well. The upper and lower chambers were filled with $1 \mathrm{ml}$ serum-free medium and $1 \mathrm{ml}$ of $10 \%$ FBS-containing medium, respectively. Following $12 \mathrm{~h}$ culture, cells in the upper chamber were treated with radiation and/or cisplatin as aforementioned, and medium with $10 \%$ FBS was added to the lower chamber for $12 \mathrm{~h}$. Migrated cells were fixed with $1 \mathrm{ml}$ of $100 \%$ methanol for $20 \mathrm{~min}$ at room temperature. After washing with PBS, cells were incubated with $1 \mathrm{ml}$ of $0.5 \%$ crystal violet staining solution at $37^{\circ} \mathrm{C}$ for $30 \mathrm{~min}$. After washing with PBS, stained cells were examined using a light microscope (magnification, x400; TH4-100; Olympus Corporation) and counted in five random fields of the images. The means of cell number per field in each treatment group were calculated and compared.

Determination of $m R N A$ expression levels by reverse transcription-quantitative PCR (RT-qPCR). MG-63 cells in the logarithmic growth stage were seeded in a 6-well plate at a density of $2 \times 10^{5} / 2 \mathrm{ml} /$ well and cultured overnight. Cells were treated by radiation and/or cisplatin as aforementioned for $12 \mathrm{~h}$. Cells were collected, and total RNA was extracted using a RaPure Total RNA Micro kit (Guangzhou Magen Biotechnology Co., Ltd.) according to the manufacturer's 
protocol. cDNA was synthesized using M-MLV (Promega Corporation) according to the manufacturer's protocol. RT-qPCR reactions were performed using a Stratagene Mx3000P (Agilent Technologies, Inc.) and SYBR Premix (Takara Bio, Inc.) according to manufacturer's protocol. The thermocycling conditions of the real time PCR were as follows: $95^{\circ} \mathrm{C}$ for $30 \mathrm{sec}, 40$ cycles at $95^{\circ} \mathrm{C}$ for $10 \mathrm{sec}$ and $60^{\circ} \mathrm{C}$ for $30 \mathrm{sec}$, then $60^{\circ} \mathrm{C}$ for $60 \mathrm{sec}$ and $95^{\circ} \mathrm{C}$ for $15 \mathrm{sec}$. GAPDH was used as the reference gene. The primers were provided by Beijing Biomedical Co. Ltd. and designed as follows: BRCA1 forward, 5'-GCTGCTGCTCATACTACTG-3' and reverse, 5'-CСАCАТСТССТCTGACTTC-3'; p53 forward, 5'-ACC ACCATCCACTACAACTAC-3' and reverse, 5'-ACAAAC ACGCACCTCAAA-3'; and GAPDH forward, 5'-ATCCCA TCACCATCTTCC-3' and reverse, 5'-TGACCCTTTTGGCTC CCC-3'. The relative expressions levels were normalized to endogenous controls and were expressed as $2^{-\Delta \Delta C q}(30)$.

Western blotting. MG-63 cells in the logarithmic growth stage were seeded in a 6 -well plate at a density of $2 \times 10^{5} / 2 \mathrm{ml} /$ well and cultured overnight. Cells were treated by radiation and/or cisplatin as aforementioned for $12 \mathrm{~h}$. Cells were lysed using lysis buffer (Beijing Dingguo Changsheng Biotechnology Co., Ltd.) and subjected to a cycle of freezing at $-70^{\circ} \mathrm{C}$ and thawing at $37^{\circ} \mathrm{C}(1 \mathrm{~h}$ per step). The protein concentration was measured using the BCA kit. Proteins $(30 \mu \mathrm{g})$ were separated by $12 \%$ SDS-PAGE and transferred onto PVDF membranes. Membranes were blocked with 5\% skimmed milk dissolved in TBS containing $0.05 \%$ Tween-20 (TBST) at $37^{\circ} \mathrm{C}$ for $1 \mathrm{~h}$ and incubated with antibodies against BRCA1 (1:700; Abcam; cat. no. ab238983), p53 (1:700; Abcam; cat. no. ab131442), Bcl-2 (1:700; Abcam; cat. no. ab196495), Bax (1:700; Abcam; cat. no. ab53154) and GAPDH (1:700; Abcam; cat. no. ab9485) at $4^{\circ} \mathrm{C}$ overnight. Following washing with TBST, membranes were incubated with horseradish peroxidase-conjugated goat anti-rabbit immunoglobulin G secondary antibody (1:1,000; ABclonal Biotech Co., Ltd.; cat. no. AS011) dissolved in TBST buffer containing $5 \%$ skimmed milk at $37^{\circ} \mathrm{C}$ for $1 \mathrm{~h}$. Following washing with TBST, enhanced chemiluminescence reagent (7sea Pharm Technology, Co. Ltd) was used to detect the signal on the membrane. Relative expression level of the proteins was normalized to the endogenous control using Quantity One software (version 4.6.9; Bio-Rad Laboratories, Inc.).

Statistical analysis. Data were expressed as the means \pm standard deviation of three independent experiments. Statistical analysis was performed using SPSS software v21.0 (IBM Corp.). Differences among groups were analyzed using one-way ANOVA followed by Least Significant Difference post-hoc analysis. $\mathrm{P}<0.05$ was considered to indicate a statistically significant difference.

\section{Results}

Effect of radiation and cisplatin on MG-63 cell proliferation. Following treatment with radiation and/or cisplatin, MG-63 cell proliferation was determined using a CCK-8 assay. The results demonstrated that the optical density (OD) values in the combined radiation and cisplatin treatment group were significantly lower than those in the radiation or cisplatin only groups, which were also significantly lower compared with the control group $(\mathrm{P}<0.001 ;$ Fig. 1). The OD values in the radiation groups were decreased in a dose-dependent manner compared with the control group ( $\mathrm{P}<0.05$; Fig. 2). Similarly, OD values in the cisplatin groups were decreased in a dose-dependent manner compared with the control group ( $\mathrm{P}<0.05$; Fig. 3 ). These results suggested that both radiation and cisplatin treatment inhibited MG-63 cell proliferation and that the combined treatment with radiation and cisplatin was even more effective.

Effects of radiation and cisplatin on MG-63 cell apoptosis. Following treatment with radiation and/or cisplatin, MG-63 cell apoptosis was determined by flow cytometry using Annexin V and PI double staining. The results revealed that the apoptosis rate in the combined radiation and cisplatin treatment group was significantly higher compared with that in the cisplatin group, but was lower compared with that in the radiation group (Fig. 4). The apoptosis rates in all these three treatment groups were significantly higher compared with the control group. MG-63 cell apoptosis rates were significantly increased in a dose-dependent manner in the radiation treatment groups, compared with the control group ( $\mathrm{P}<0.05$; Fig. 5). MG-63 cell apoptosis rates were also significantly increased in a dose-dependent manner in the cisplatin treatment groups compared with the control group $(\mathrm{P}<0.05$; Fig. 6).

Effects of radiation and cisplatin on MG-63 cell cycle. MG-63 cells were treated with radiation and/or cisplatin, and the cell cycle distribution was determined by flow cytometry. The results demonstrated that the ratio of cells in the $G_{1}$ phase was significantly decreased in the radiation, cisplatin and combined radiation and cisplatin treatment groups, compared with the control group. The ratio of cells in the $G_{1}$ phase was significantly decreased in the combined radiation and cisplatin treatment group, compared with the cisplatin group. There was no significant difference in the ratio of cells in $G_{1}$ phase between the combined radiation and cisplatin treatment group and the radiation groups (Fig. 7A and B). The ratio of cells in $\mathrm{G}_{2}$ phase was significantly increased in the radiation, cisplatin and combined radiation and cisplatin treatment groups, compared with the control group. The ratio of cells in $G_{2}$ phase was significantly increased in the combined radiation and cisplatin treatment group compared with the cisplatin group. The ratio of cells in $G_{2}$ was significantly decreased in the combined radiation and cisplatin treatment group compared with the radiation group (Fig. 7A and C). The ratio of cells in S phase was significantly increased in the cisplatin and combined radiation and cisplatin treatment groups, and was decreased in the radiation group, compared with the control group. The ratio of cells in $\mathrm{S}$ phase was significantly increased in the combined radiation and cisplatin treatment group compared with the cisplatin group and the radiation group (Fig. 7A and D). Consistently, the ratios of cells in $\mathrm{G}_{1}$ (Fig. 8A and B) and $\mathrm{S}$ (Fig. 8A and D) phases were significantly decreased and the ratio of cells in $\mathrm{G}_{2}$ phase (Fig. 8A and C) was significantly increased in the radiation treatment group. The ratios of cells in $\mathrm{G}_{1}$ (Fig. 9A and $B$ ) were significantly decreased and the ratios of cells in $\mathrm{G}_{2}$ phase (Fig. 9A and C) and $\mathrm{S}$ phase (Fig. 9A and D) were significantly increased in the cisplatin treatment group. These results revealed that treatment with radiation resulted in $\mathrm{G}_{2}$ 


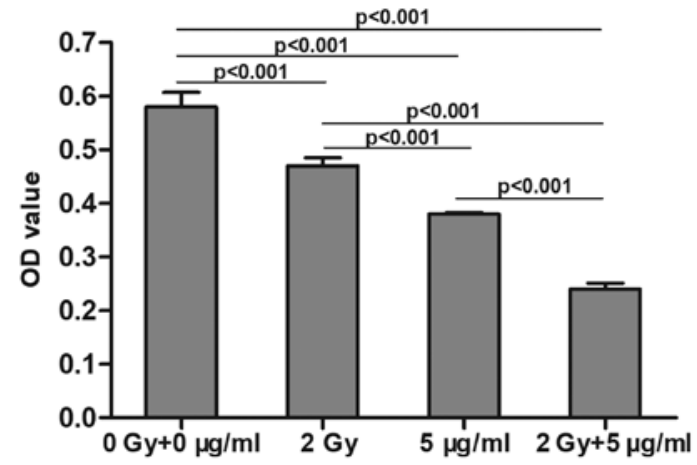

Figure 1. Effects of radiation and cisplatin treatment on MG-63 cell proliferation. MG-63 cells were seeded and cultured overnight and treated with radiation and/or cisplatin. After $12 \mathrm{~h}$, cell proliferation was determined using the Cell Counting Kit-8 assay. OD, optical density.

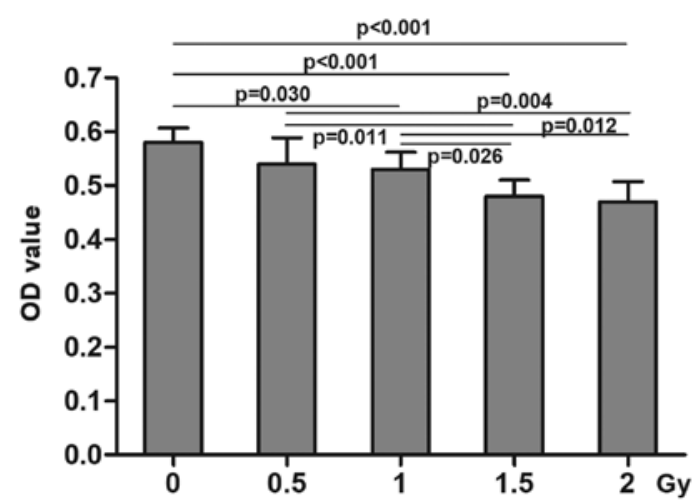

Figure 2. Effects of radiation on MG-63 cell proliferation. MG-63 cells were seeded and cultured overnight and treated with radiation. After $12 \mathrm{~h}$, cell proliferation was determined using the Cell Counting Kit-8 assay. OD, optical density.

phase arrest in MG-63 cells, and treatment with cisplatin or combined radiation and cisplatin resulted in both $\mathrm{G}_{2}$ phase arrest and $\mathrm{S}$ phase arrest. The effects of cisplatin on both $\mathrm{G}_{2}$ phase arrest and $S$ phase arrest were less clear than those of combined radiation and cisplatin treatment.

Effects of radiation and cisplatin on MG-63 cell migration . MG-63 cells were treated with radiation and/or cisplatin, and MG-63 cell migration was determined by Transwell assays. The results demonstrated that the number of invasive cells was lower in the combined radiation and cisplatin treatment group compared with the radiation or cisplatin treatment groups, which were lower than that in the control group (Fig. 10). The number of invasive cells was significantly decreased in a dose-dependent manner in the radiation treatment groups, compared with the control group $(\mathrm{P}<0.05 ;$ Fig. 11). The number of invasive cells was significantly decreased in a dose-dependent manner in the cisplatin treatment group, compared with the control group $(\mathrm{P}<0.05$; Fig. 12).

Effects of radiation and cisplatin on BRCA1 and p53 expression in $M G-63$ cells. Following treatment with radiation and/or cisplatin, the mRNA and protein expression levels of BRCA1 and 533 were determined in MG- 63 cells by RT-qPCR and western blotting, respectively. The results demonstrated

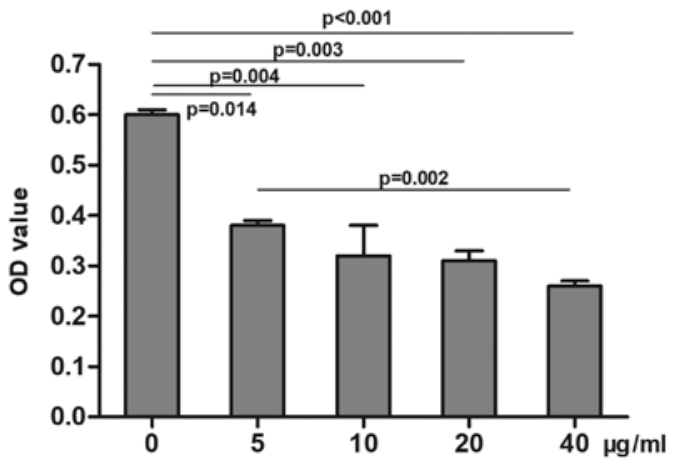

Figure 3. Effects of cisplatin on MG-63 cell proliferation. MG-63 cells were seeded and cultured overnight and treated with cisplatin. After $12 \mathrm{~h}$, cell proliferation was determined using the Cell Counting Kit- 8 assay. OD, optical density.

that BRCA1 mRNA level was significantly decreased in the combined radiation and cisplatin treatment group, compared with those in the radiation or cisplatin treatment groups, and the BRCA1 mRNA levels in these three treatment groups were lower than that of the control group $(\mathrm{P}<0.05$; Fig. 13A). BRCA1 mRNA level was significantly decreased in the radiation treatment group in a dose-dependent manner, compared with the control group $(\mathrm{P}<0.05$; Fig. 14A). BRCA1 mRNA level was significantly decreased in the cisplatin treatment group in a dose-dependent manner compared with the control group $(\mathrm{P}<0.05$; Fig. 15A). Similar results were obtained for the p53 mRNA level (Figs. 13B, 14B and 15B). Furthermore, BRCA1 protein expression was significantly decreased in the combined radiation and cisplatin treatment group, compared with the radiation and cisplatin treatment groups and the control group $(\mathrm{P}<0.05$; Fig. $13 \mathrm{C}$ and $\mathrm{D})$. BRCA1 protein expression was significantly decreased in the radiation treatment group (Fig. 14C and D) and the cisplatin treatment group (Fig. 15C and D) in a dose-dependent manner, compared with the control group $(\mathrm{P}<0.05)$. In addition, p53 protein expression was significantly decreased in the combined radiation and cisplatin treatment group, the radiation group and the cisplatin group compared with the control group $(\mathrm{P}<0.05$; Fig. $13 \mathrm{C}$ and $\mathrm{E})$. The $\mathrm{p} 53$ protein expression was decreased in the radiation treatment group (Fig. 14C and E) and the cisplatin treatment group (Fig. 15C and E), compared with the control group $(\mathrm{P}<0.05)$. These results revealed that the combined treatment with radiation and cisplatin induced a decrease in the mRNA and protein expression levels of BRCA1 and p53 in MG-63 cells. The combination of radiation and cisplatin exhibited a more potent inhibitory effect on $\mathrm{p} 53$ protein expression compared with BRCA1 protein expression in MG-63 cells.

Effects of radiation and cisplatin on Bax and Bcl-2 levels in MG-63 cells. MG-63 cells were treated with radiation and/or cisplatin and the Bax and Bcl-2 protein levels were determined by western blotting. The results demonstrated that Bax expression was significantly decreased in the radiation, cisplatin and combined radiation and cisplatin treatment groups, compared with the control group $(\mathrm{P}<0.001)$, and that Bax expression was lower in the combined radiation and cisplatin treatment group than in the radiation or cisplatin 


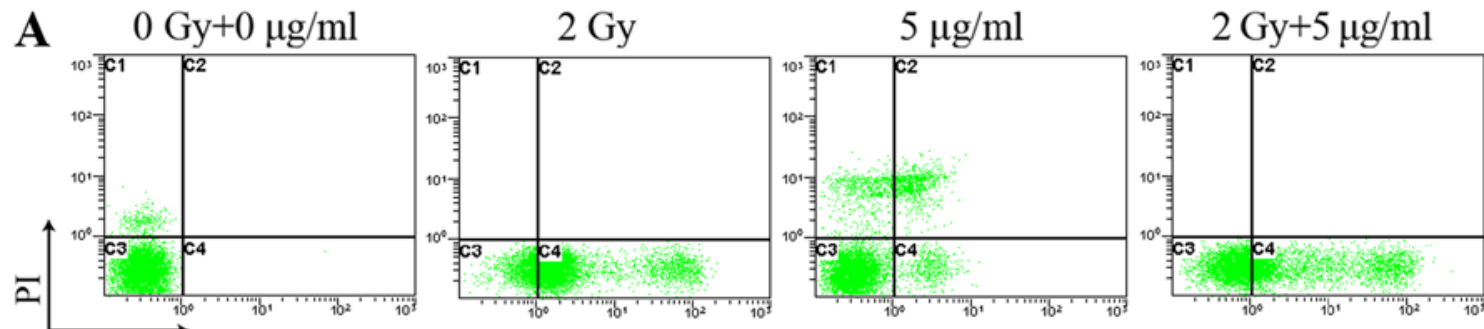

Annexin V

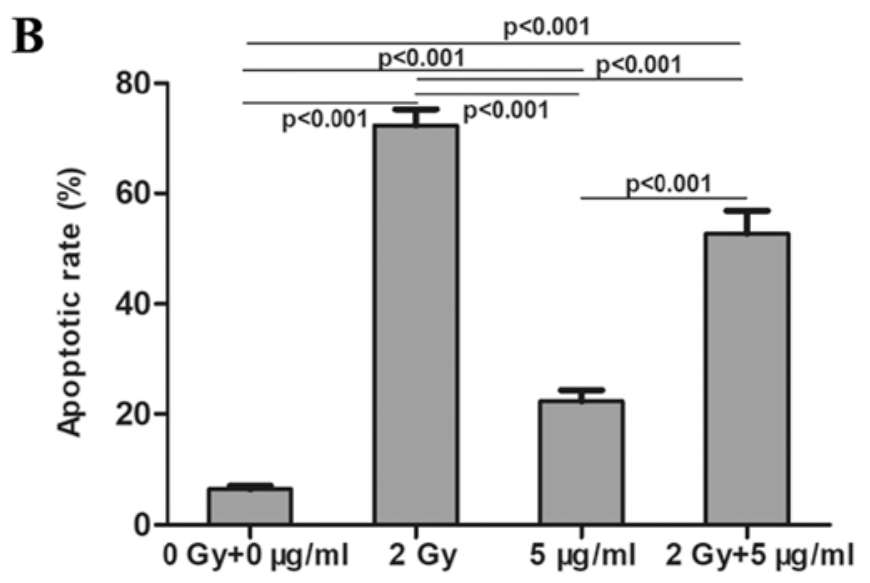

Figure 4. Effects of radiation and cisplatin on MG-63 cell apoptosis. MG-63 cells were seeded and cultured overnight and treated with radiation and/or cisplatin. After $12 \mathrm{~h}$, cell apoptosis was determined by flow cytometry following Annexin V and PI double staining. (A) Representative results obtained using flow cytometry. (B) Analysis of the results obtained using flow cytometry. PI, propidium iodide.
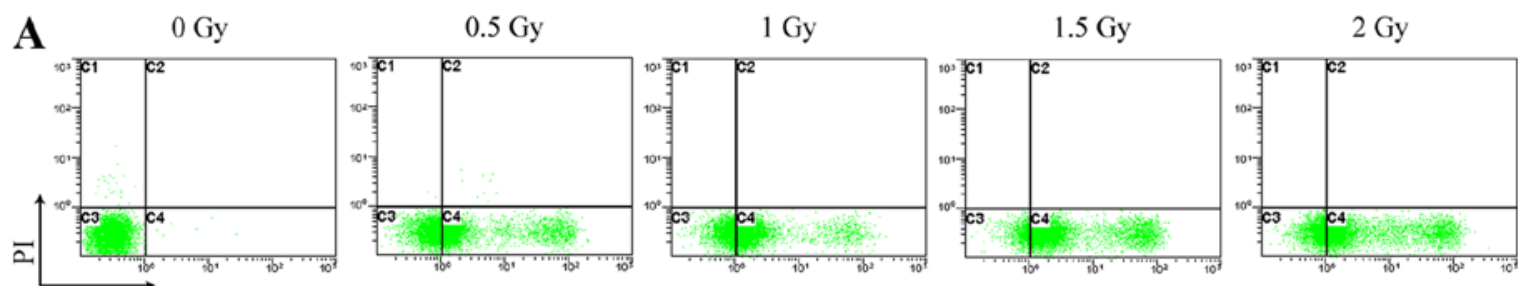

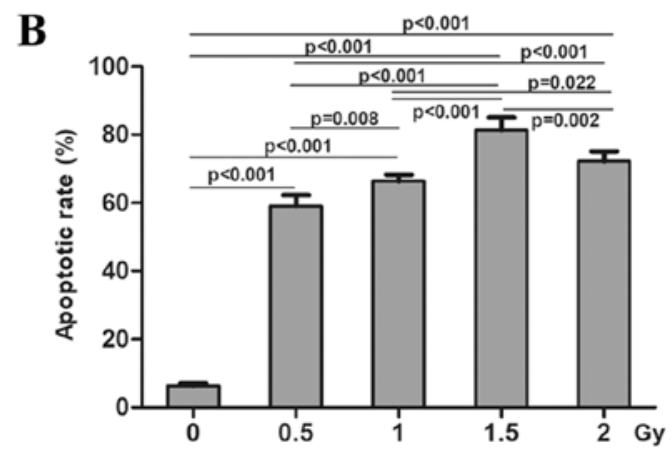

Figure 5. Effects of radiation on MG-63 cell apoptosis. MG-63 cells were seeded and cultured overnight and treated with radiation. After 12 h, cell apoptosis was determined by flow cytometry following Annexin V and PI double staining. (A) Representative results obtained using flow cytometry. (B) Analysis of the results obtained using flow cytometry. PI, propidium iodide.

only treatment groups $(\mathrm{P}<0.001$; Fig. $13 \mathrm{C}$ and $\mathrm{F})$. Bax protein expression was significantly decreased in the radiation treatment group (Fig. 14C and F) and the cisplatin treatment group (Fig. 15C and F) in a dose-dependent manner compared with the control group $(\mathrm{P}<0.05)$. Furthermore, Bcl-2 protein expression was significantly increased in the radiation, cisplatin and combined radiation and cisplatin treatment groups, compared with the control group $(\mathrm{P}<0.001)$. In addition, Bcl-2 expression was significantly higher in the combined radiation and cisplatin treatment group, compared with those of the radiation and cisplatin treatment groups $(\mathrm{P}<0.05$; Fig. $13 \mathrm{C}$ and $\mathrm{G})$. Bcl-2 protein expression was significantly increased in the radiation treatment group (Fig. 14C and G) and the cisplatin treatment group (Fig. 15C and G) in a dose-dependent manner compared 

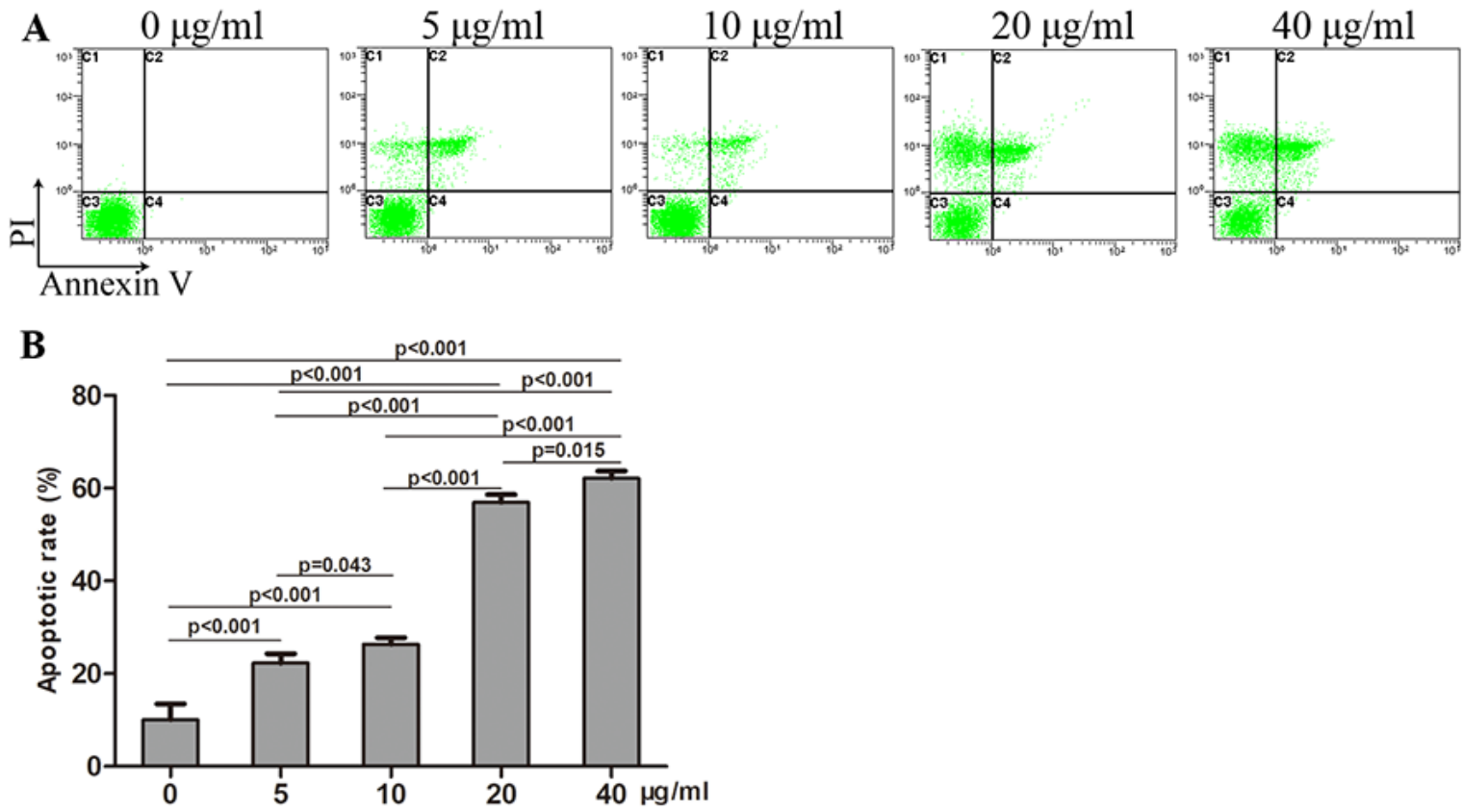

Figure 6. Effects of cisplatin on MG-63 cell apoptosis. MG-63 cells were seeded and cultured overnight and treated with cisplatin. After 12 h, cell apoptosis was determined by flow cytometry following Annexin V and PI double staining. (A) Representative results obtained using flow cytometry. (B) Analysis of the results obtained using flow cytometry. PI, propidium iodide.

A

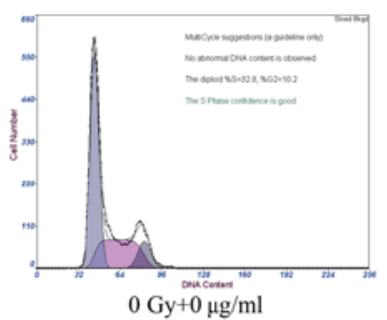

B

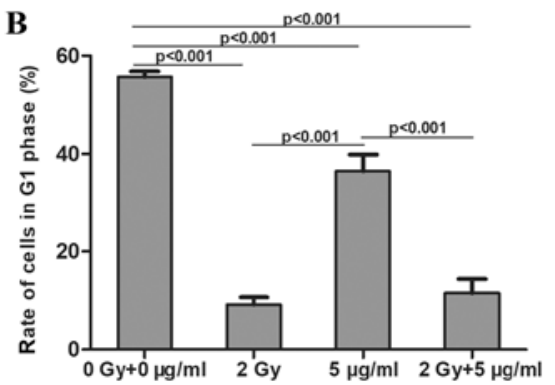

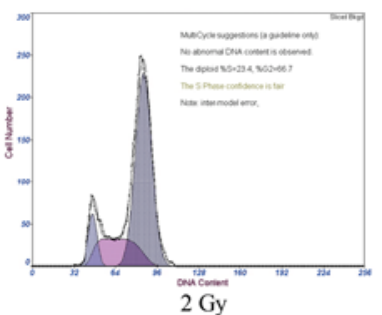

C

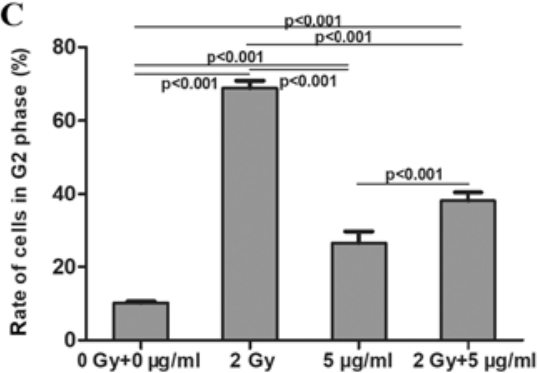

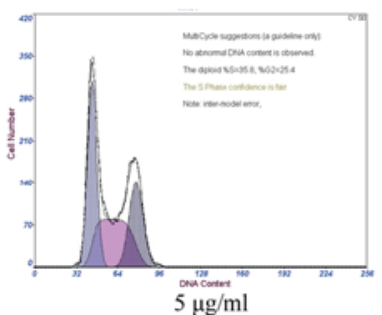

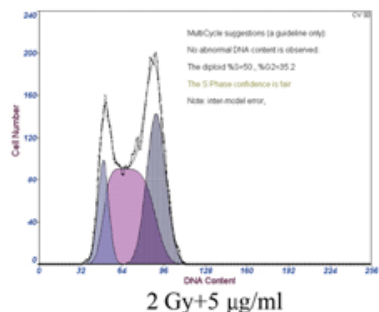

D

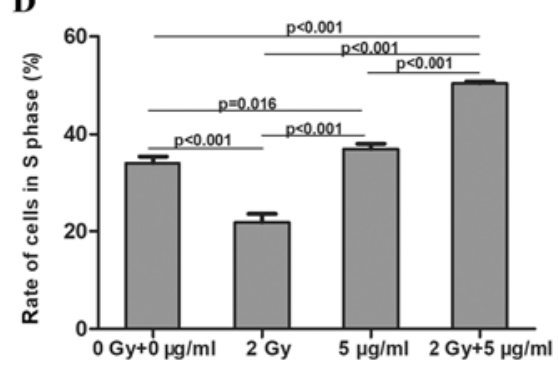

Figure 7. Effects of radiation and cisplatin on MG-63 cell cycle. MG-63 cells were seeded and cultured overnight and treated with radiation and/or cisplatin. (A) After $12 \mathrm{~h}$, cell cycle was determined by flow cytometry. Quantification of the effects of radiation and cisplatin on (B) $G_{1}$ phase, $(C) G_{2}$ phase and (D) S phase of MG-63 cell cycle.

with the control group $(\mathrm{P}<0.05)$. These results indicated that the combined treatment with radiation and cisplatin exhibited a more potent inhibitory effect on Bax protein expression and an inductive effect on Bcl-2 protein expression, compared with radiation and cisplatin treatments alone in MG-63 cells.

\section{Discussion}

The present study demonstrated that the combined treatment of radiation and cisplatin significantly inhibited MG-63 cell proliferation in a more potent way compared with radiation or cisplatin treatments alone. Furthermore, the three treatments increased the apoptosis rates of MG-63 cells, induced MG- 63 cell arrest in the $G_{2}$ phase and significantly decreased the migratory capacity of MG-63 cells. In addition, the apoptosis rate in the combined radiation and cisplatin treatment group was higher than that in the cisplatin group, but lower than that in the radiation group. Furthermore, the combined treatment of radiation and cisplatin resulted in MG-63 cell arrest in the $\mathrm{S}$ phase and in a lower number of migratory cells compared with radiation of cisplatin treatment alone. These results suggested that combining radiation and cisplatin 
A
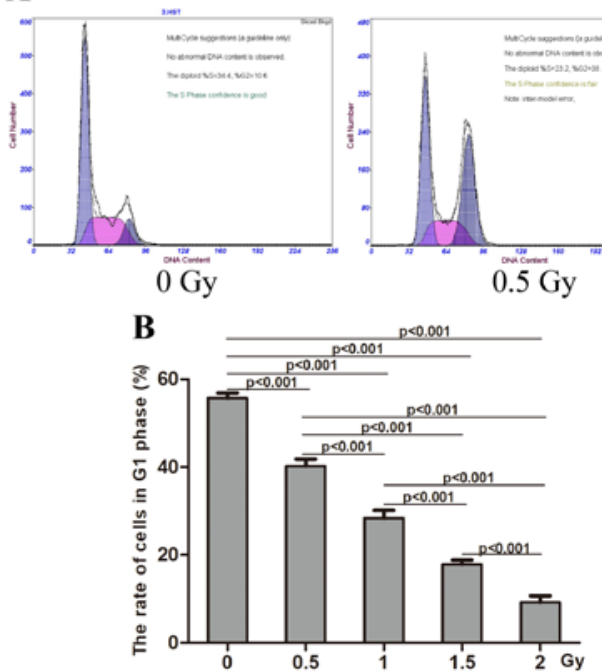

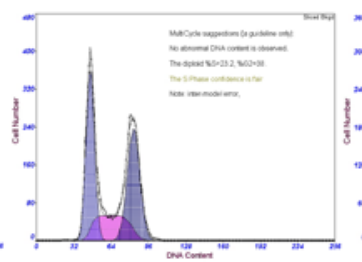

C

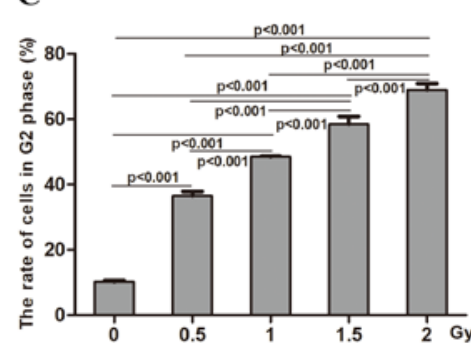

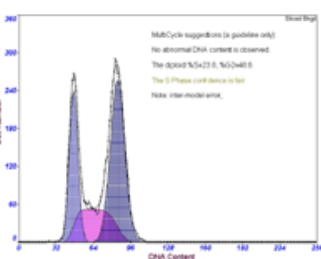

$1 \mathrm{~Gy}$

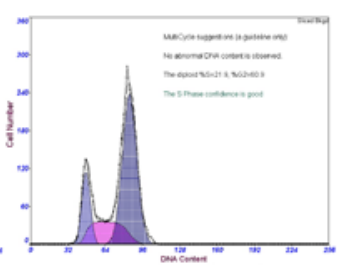

$1.5 \mathrm{~Gy}$

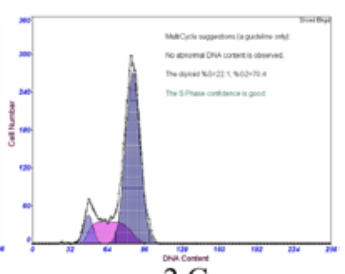

$2 \mathrm{~Gy}$

D

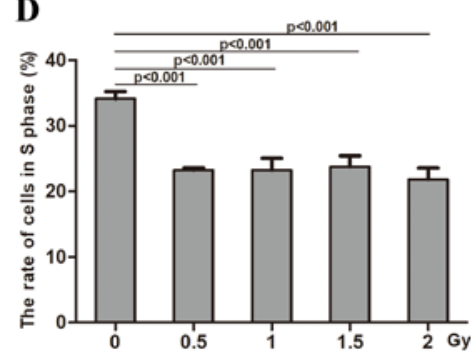

Figure 8. Effects of radiation on MG-63 cell cycle. MG-63 cells were seeded and cultured overnight and treated with radiation. (A) After 12 h, cell cycle was determined by flow cytometry. Quantification of the effects of radiation on (B) $\mathrm{G}_{1}$ phase, (C) $\mathrm{G}_{2}$ phase and (D) $\mathrm{S}$ phase of $\mathrm{MG}-63$ cell cycle.

A
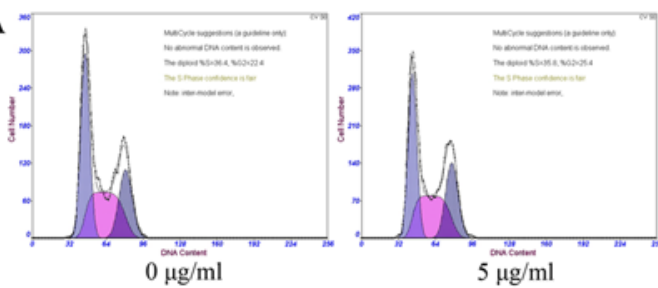

B

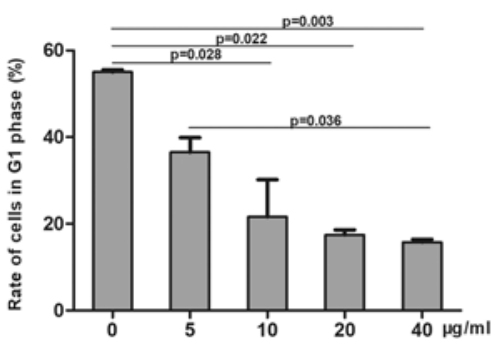

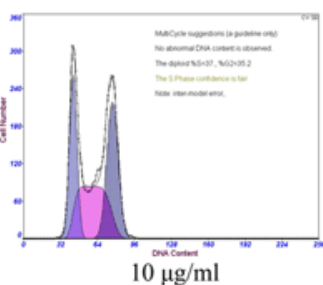

C

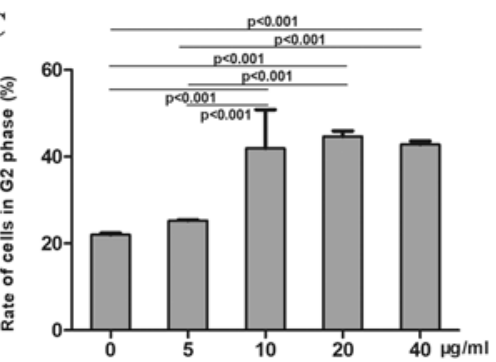

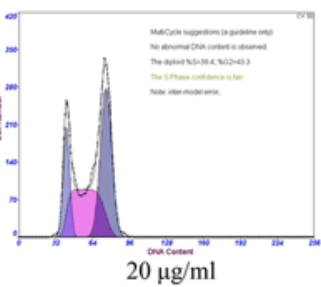

D

Figure 9. Effects of cisplatin on MG-63 cell cycle. MG-63 cells were seeded and cultured overnight and treated with cisplatin. (A) After 12 h, cell cycle was determined by flow cytometry. Quantification of the effects of cisplatin on (B) $G_{1}$ phase, (C) $G_{2}$ phase and (D) $S$ phase of MG-63 cell cycle.

treatment may have a more potent therapeutic effect on MG-63 osteosarcoma compared with radiation or cisplatin treatments alone.

Radiation exerts detrimental effects on tumor cells through direct breaking of DNA strands, lipids and proteins and indirect bystander effects, resulting in DNA damage, chromosomal instability, gene mutation and apoptosis $(31,32)$. Cisplatin induces the formation of platinum-DNA adducts, which results in the breakage and damage of single- and double-stranded DNA and the inhibition of tumor cell division, leading to tumor cell death $(33,34)$. Therefore, combined treatment of radiation and cisplatin may cause inhibition of proliferation and division of tumor cells through several molecular and cellular antitumor mechanisms, including enhanced apoptosis and cell cycle arrest, as previously demonstrated for the treatment of head and neck cancer and cervical cancer (35-37). Similarly, the results from the present study demonstrated that the combined treatment of radiation and cisplatin exhibited superior therapeutic effects on osteosarcoma MG-63 cells compared with radiation or cisplatin treatments alone. These findings may be due to mutually enhanced effects of radiation and cisplatin resulting from various molecular and cellular antitumor mechanisms.

The present study demonstrated that combining radiation and cisplatin was more potent in inhibiting MG-63 cell proliferation and migration compared with radiation or cisplatin treatments alone. The dose used in the present study is $2.0 \mathrm{~Gy}$ radiation $+5 \mathrm{~g} / \mathrm{ml}$ cisplatin. However, the effect of combined radiation and cisplatin treatment on cell cycle $\mathrm{G}_{2}$ arrest and apoptosis is less than those of radiation treatment and greater than those of cisplatin treatment. These results suggested that the regulation of MG-63 cell apoptosis and cell cycle by the combined treatment of radiation and cisplatin may be due to a different mechanism compared with radiation or 
A
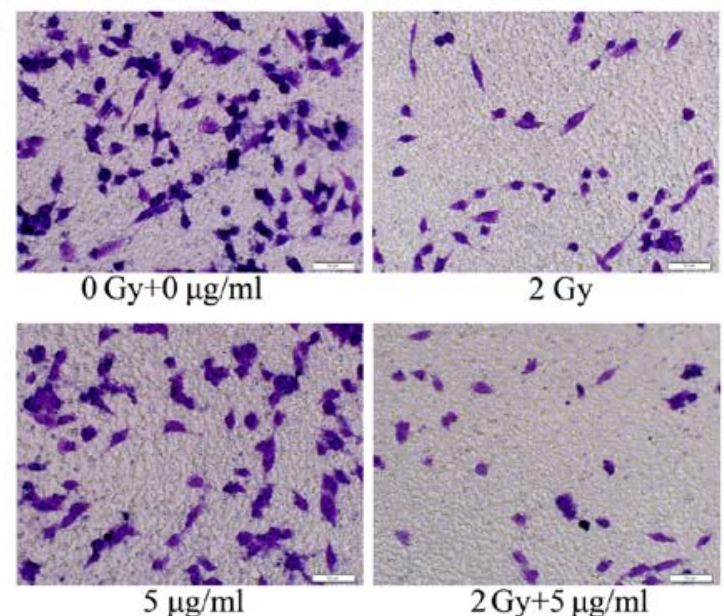

B

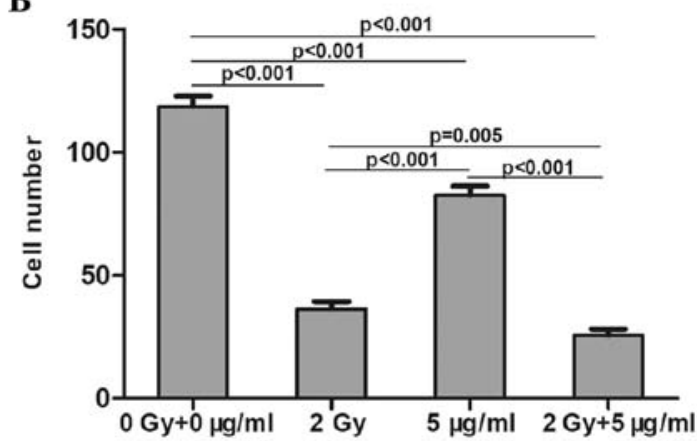

Figure 10. Effects of radiation and cisplatin on MG-63 cell migration. MG-63 cells were seeded and cultured overnight and treated with radiation and/or cisplatin. After 12 h, MG-63 cell migration was determined by Transwell assay. (A) Representative results obtained from Transwell assay. Scale bar, $50 \mu$ m. (B) Analysis of the results obtained from Transwell assay.

A

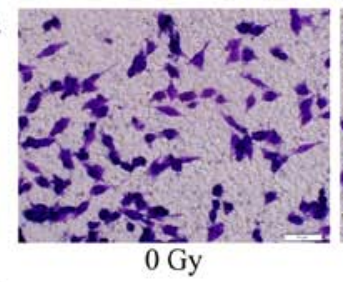

B

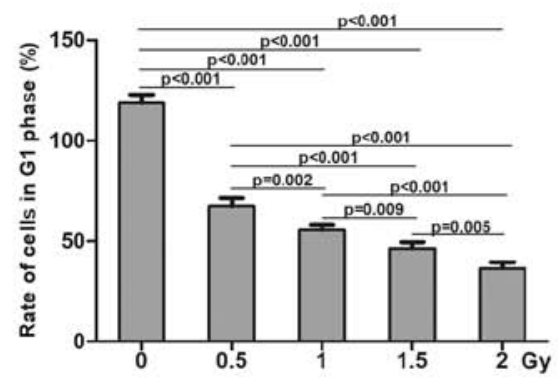

Figure 11. Effects of radiation on MG-63 cell migration. MG-63 cells were seeded and cultured overnight and treated with radiation. After 12 h, MG-63 cell migration was determined by Transwell assay. (A) Representative results obtained from Transwell assay. Scale bar, $50 \mu \mathrm{m}$. (B) Analysis of the results obtained from Transwell assay.

cisplatin treatments alone, and may therefore require further investigation.

The results of the present study revealed that combined treatment with radiation and cisplatin resulted in decreased mRNA and protein expression levels of BRCA1 and p53. Furthermore, the combined treatment of radiation and cisplatin exhibited a more potent inhibitory effect on p53 expression in MG-63 cells compared with BRCA1 expression. In addition, the combined treatment of radiation and cisplatin was more potent in decreasing Bax protein expression and increasing $\mathrm{Bcl}-2$ protein expression compared with radiation and cisplatin treatments alone in MG-63 cells. These findings suggested that the BRCA1-p53 signaling pathway may mediate the effects of combined treatment of radiation and cisplatin on MG-63 cells. BRCA1 is a tumor suppressor gene involved in multiple cell signaling pathways, including the damaged DNA repair pathway and cell cycle regulation (38). The low expression levels and high rates of mutation of BRCA1 can decrease DNA repair capacity in cancer cells, including ovarian cancer and breast cancer cells, resulting in cell insensitivity to platinum and other platinum drugs (39-43). In addition, DNA is the main target of radiation, and BRCA1 mutation is associated with radiation sensitivity (44-46). Therefore, BRCA1 expression may be negatively associated with the effects of platinum drugs and radiation on tumor cells, which was demonstrated in the present study. Therefore, determining how low BRCA1 expression may be associated with the effect of radiation and cisplatin treatment on osteosarcoma requires further investigation.

Bax is a pro-apoptotic protein and $\mathrm{Bcl}-2$ is an anti-apoptotic protein. They mediate the intrinsic apoptosis pathway by controlling mitochondrial outer membrane integrity $(47,48)$. The results of the present study demonstrated that combining radiation and cisplatin had a more potent effect in decreasing Bax protein expression and increasing $\mathrm{Bcl}-2$ protein expression compared with radiation or cisplatin treatments alone 

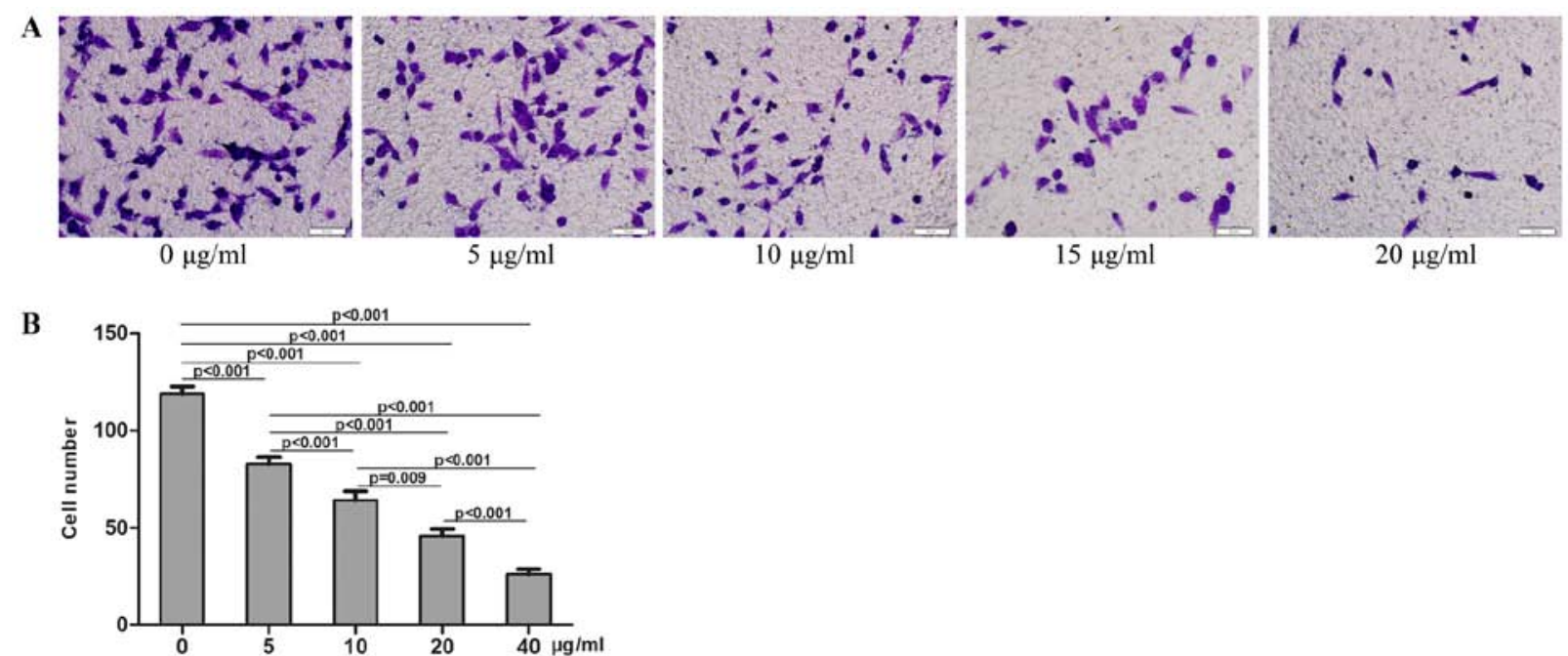

Figure 12. Effects of cisplatin on MG-63 cell migration. MG-63 cells were seeded and cultured overnight and treated with cisplatin. After 12 h, MG-63 cell migration was determined by Transwell assay. (A) Representative results obtained from Transwell assay. Scale bar, $50 \mu \mathrm{m}$. (B) Analysis of the results obtained from Transwell assay.
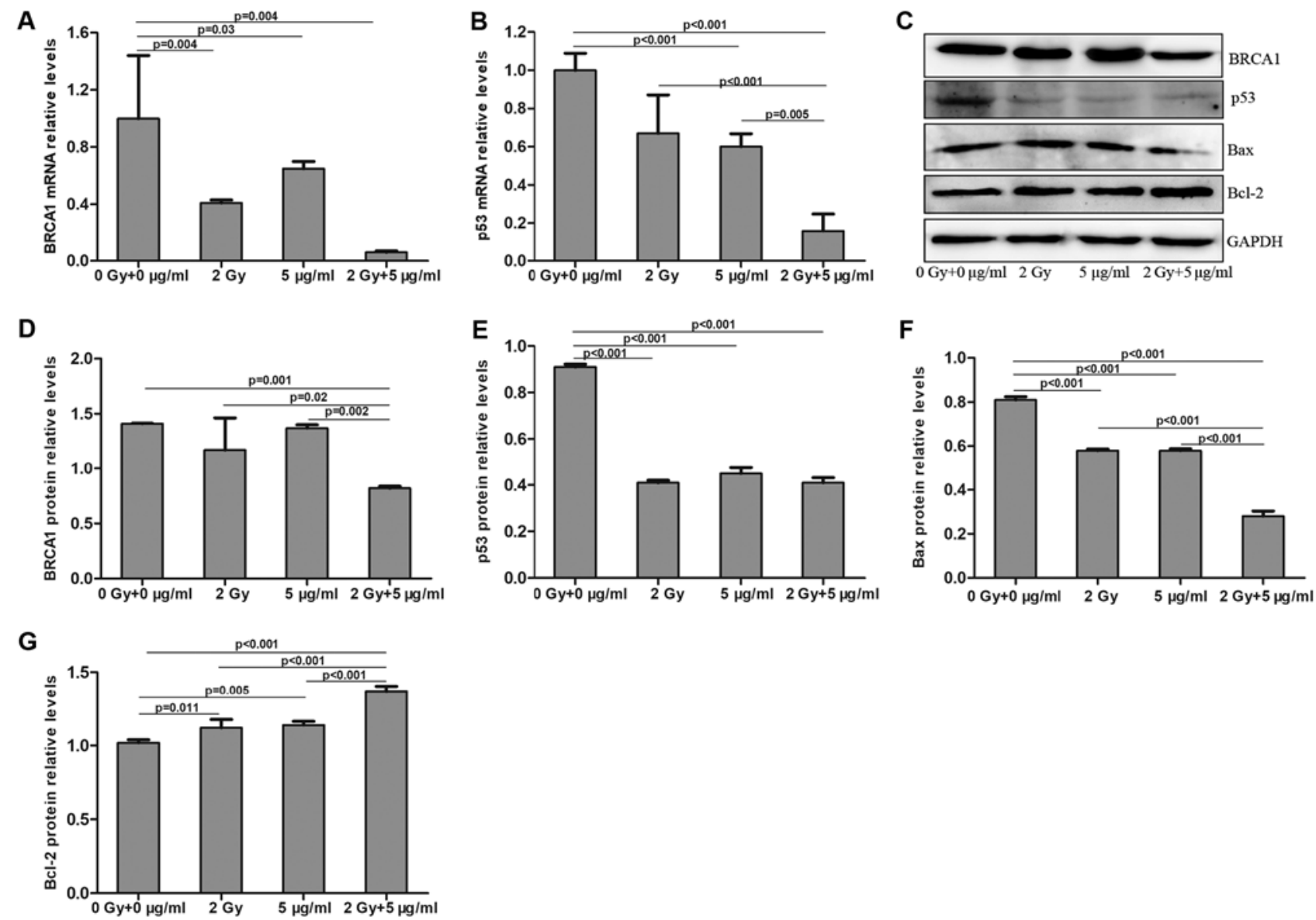

Figure 13. Effects of radiation and cisplatin on the expression levels of BRCA1, p53, Bax and Bcl-2 in MG-63 cells. MG-63 cells were seeded and cultured overnight and treated with radiation and/or cisplatin. After $12 \mathrm{~h}$, cells were collected for further analysis. (A) BRCA1 and (B) p53 mRNA expression levels were determined by reverse transcription-quantitative PCR. (C) Protein expression levels of (D) BRCA1, (E) p53, (F) Bax and (G) Bcl-2 were determined by western blotting and semi-quantified using Quantity One software. BRCA1, breast cancer 1.

in MG-63 cells. Previous studies reported inconsistent findings on a rat tumor model of human small cell lung cancer where Bcl-2 expression was increased in cisplatin-resistant subline (GLC4-CDDP) following combined treatment (49), in esophageal squamous cell carcinoma where neither Bcl-2 nor Bax expression were associated with the efficacy of therapy (50), and in non-small cell lung cancer where high expression of Bcl-2 in tumors was significantly associated 
A

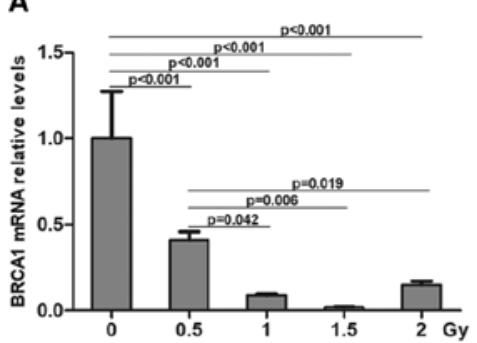

D
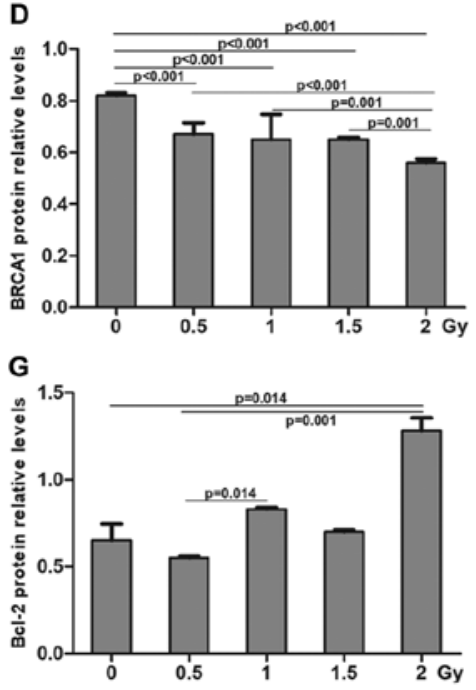

B

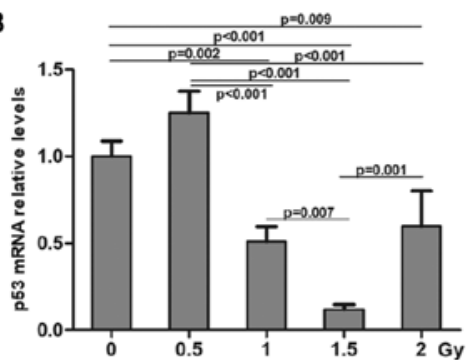

E

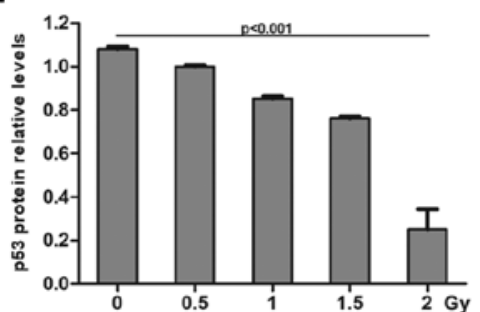

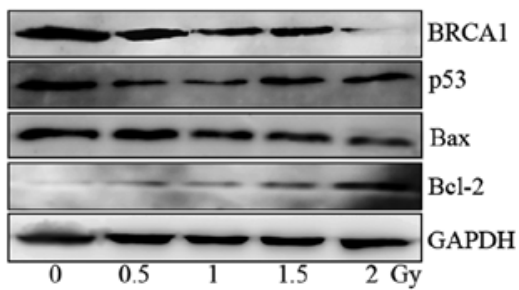

$\mathbf{F}$

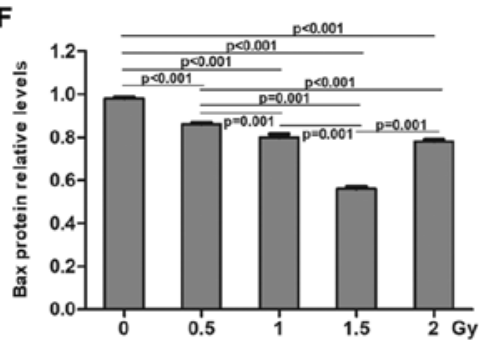

Figure 14. Effects of radiation on the expression of BRCA1, p53, Bax and Bcl-2 in MG-63 cells. MG-63 cells were seeded and cultured overnight and treated with radiation. After $12 \mathrm{~h}$, cells were collected for further analysis. (A) BRCA1 and (B) p53 mRNA expression levels were determined by reverse transcription-quantitative PCR. (C) Protein expression levels of (D) BRCA1, (E) p53, (F) Bax and (G) Bcl-2 were determined by western blotting and semi-quantified using Quantity One software. BRCA1, breast cancer 1.

A

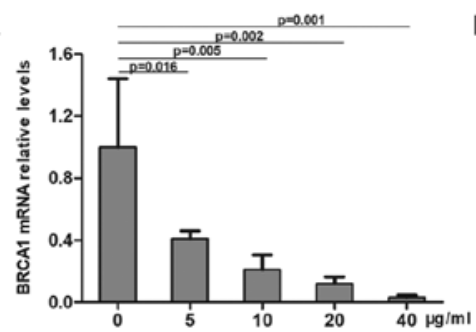

D

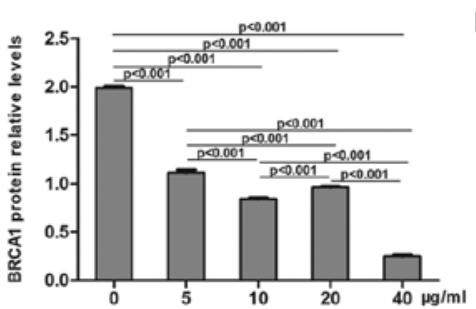

G

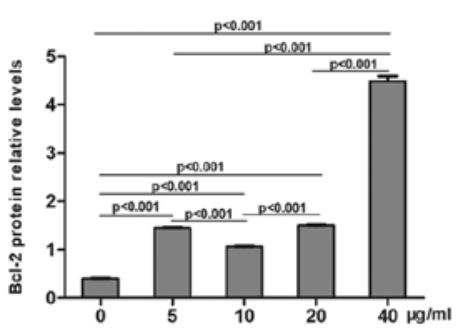

B

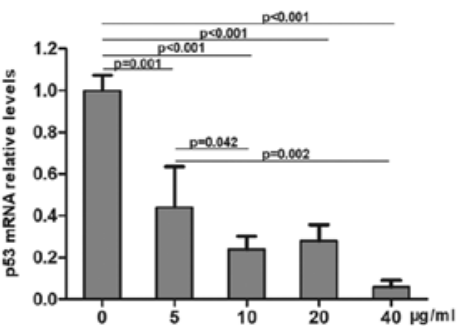

E

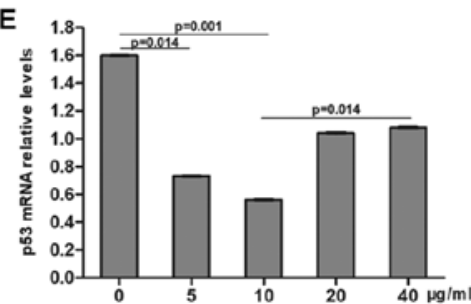

C

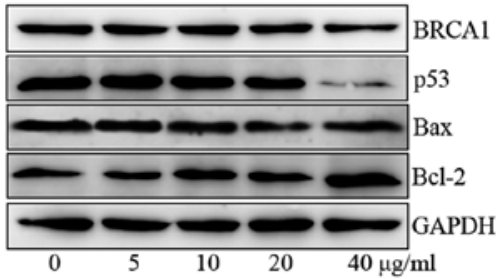

$\mathbf{F}$

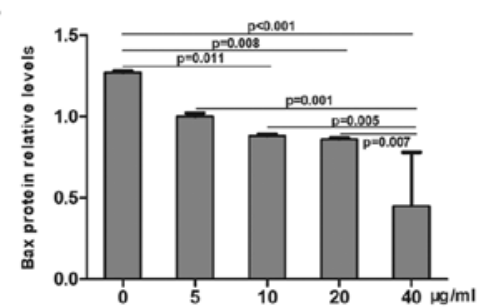

Figure 15. Effects of cisplatin on the expression levels of BRCA1, p53, Bax and Bcl-2 in MG-63 cells. MG-63 cells were seeded and cultured overnight and treated with cisplatin. After $12 \mathrm{~h}$, cells were collected for further analysis. (A) BRCA1 and (B) p53 mRNA expression levels were determined by reverse transcription-quantitative PCR. (C) Protein levels of (D) BRCA1, (E) p53, (F) Bax and (G) Bcl-2 were determined by western blotting and semi-quantified using Quantity One software. BRCA1, breast cancer 1. 
with longer survival duration (51). The heterogeneous nature of the tumor and the numerous apoptotic pathways involved in cancer may account for these differences (52-54).

The current study presented some limitations. Firstly, the present study only examined the effect of single doses of cisplatin and radiation and of combined treatment in only one cell line and at only one time point. Additional cell lines, multiple doses of treatment and more combinations will be examined in future studies. Secondly, this study only measured cell proliferation using a CCK-8 assay to determine treatment efficacy. The assessment of colony formation to detect cell viability following therapy will be conducted in future studies. Thirdly, increased levels of the tumor suppressor p53 are usually induced by radiation through DNA damage; however, the present study revealed that the p53 level was decreased following treatment with radiation and cisplatin. The underlying mechanism require further investigation.

In conclusion, treatment with radiation and cisplatin, alone or in combination, inhibited cell proliferation and migration, induced cell cycle arrest in $\mathrm{G}_{2}$ phase, stimulated cell apoptosis, decreased the expression levels of BRCA1 and p53, decreased Bax protein expression and increased $\mathrm{Bcl}-2$ protein expression in MG-63 cells, suggesting that the BRCA1-p53 signaling pathway may serve a crucial role. Furthermore, combined treatment with radiation and cisplatin exhibited more potent effects in inducing these phenomena compared with radiation or cisplatin treatments alone. These findings suggested that combining radiation and cisplatin may be considered a good approach for the treatment of osteosarcoma and that the BRCA1 level may be used to evaluate treatment efficacy in MG-63 cells.

\section{Acknowledgements}

Not applicable.

\section{Funding}

The present study was supported by the Jilin Scientific and Technological Development Program (grant no. 20180520109JH) and the Science and Technology project of the Education Department of Jilin Province during the '13th Five-Year Plan' (grant no. JJKH20180203KJ).

\section{Availability of data and materials}

The datasets used and/or analyzed during the current study are available from the corresponding author on reasonable request.

\section{Authors' contributions}

HBS, HYW, BW and LNZ designed the study. HBS, HYW, BW, ZFW, LZW, FQL, JDW and LNZ collected and analyzed the data. HBS, HYW, BW and LNZ drafted and wrote the manuscript. HBS and LNZ critically revised the manuscript for intellectual content. All authors provided intellectual input to the study and approved the final version of the manuscript.

\section{Ethics approval and consent to participate}

Not applicable.

\section{Patient consent for publication}

Not applicable.

\section{Competing interests}

The authors declare that they have no competing interests.

\section{References}

1. Mirabello L, Troisi RJ and Savage SA: International osteosarcoma incidence patterns in children and adolescents, middle ages and elderly persons. Int J Cancer 125: 229-234, 2009.

2. Mirabello L, Troisi RJ and Savage SA: Osteosarcoma incidence and survival rates from 1973 to 2004: Data from the Surveillance, Epidemiology, and End Results Program. Cancer 115: 1531-1543, 2009.

3. Yang Y, Han L, He Z, Li X, Yang S, Yang J, Zhang Y, Li D, Yang $\mathrm{Y}$ and Yang $\mathrm{Z}$ : Advances in limb salvage treatment of osteosarcoma. J Bone Oncol 10: 36-40, 2017.

4. McGuire J, Utset-Ward TJ, Reed DR and Lynch CC: Re-calculating! Navigating through the osteosarcoma treatment roadblock. Pharmacol Res 117: 54-64, 2017.

5. Luetke A, Meyers PA, Lewis I and Juergens H: Osteosarcoma treatment-where do we stand? A state of the art review. Cancer Treat Rev 40: 523-532, 2014.

6. Friebele JC, Peck J, Pan X, Abdel-Rasoul M and Mayerson JL: Osteosarcoma: A meta-analysis and review of the literature. Am J Orthop (Belle Mead NJ) 44: 547-553, 2015.

7. Bacci $G$ and Lari S: Adjuvant and neoadjuvant chemotherapy in osteosarcoma. Chir Organi Mov 86: 253-268, 2001.

8. Carrle D and Bielack SS: Current strategies of chemotherapy in osteosarcoma. Int Orthop 30: 445-451, 2006.

9. Ferrari S and Serra M: An update on chemotherapy for osteosarcoma. Expert Opin Pharmacother 16: 2727-2736, 2015.

10. Anninga JK, Gelderblom H, Fiocco M, Kroep JR, Taminiau AH, Hogendoorn PC and Egeler RM: Chemotherapeutic adjuvant treatment for osteosarcoma: Where do we stand? Eur J Cancer 47: 2431-2445, 2011.

11. Bacci G, Ferrari S, Longhi A, Picci P, Mercuri M, Alvegard TA, Saeter G, Donati D, Manfrini M,Lari S, et al: High dose ifosfamide in combination with high dose methotrexate, adriamycin and cisplatin in the neoadjuvant treatment of extremity osteosarcoma: Preliminary results of an Italian Sarcoma Group/Scandinavian Sarcoma Group pilot study. J Chemother 14: 198-206, 2002.

12. Bodmer N, Walters DK and Fuchs B: Pemetrexed, a multitargeted antifolate drug, demonstrates lower efficacy in comparison to methotrexate against osteosarcoma cell lines. Pediatr Blood Cancer 50: 905-908, 2008.

13. Duffaud F, Egerer G, Ferrari S, Rassam H, Boecker U and Bui-Nguyen B: A phase II trial of second-line pemetrexed in adults with advanced/metastatic osteosarcoma. Eur J Cancer 48: 564-570, 2012.

14. Machak GN, Tkachev SI, Solovyev YN, Sinyukov PA, Ivanov SM, Kochergina NV, Ryjkov AD, Tepliakov VV, Bokhian BY and Glebovskaya VV: Neoadjuvant chemotherapy and local radiotherapy for high-grade osteosarcoma of the extremities. Mayo Clin Proc 78: 147-155, 2003.

15. Chou AJ and Gorlick R: Chemotherapy resistance in osteosarcoma: Current challenges and future directions. Expert Rev Anticancer Ther 6: 1075-1085, 2006.

16. Li S, Sun W, Wang H, Zuo D, Hua Y and Cai Z: Research progress on the multidrug resistance mechanisms of osteosarcoma chemotherapy and reversal. Tumour Biol 36: 1329-1338, 2015.

17. Ozaki T, Flege S, Kevric M, Lindner N, Maas R, Delling G, Schwarz R, von Hochstetter AR, Salzer-Kuntschik M, Berdel WE, et al: Osteosarcoma of the pelvis: Experience of the Cooperative Osteosarcoma Study Group. J Clin Oncol 21: 334-341, 2003.

18. Ozaki T, Flege S, Liljenqvist U, Hillmann A, Delling G, Salzer-Kuntschik M, Jürgens H, Kotz R, Winkelmann W and Bielack SS: Osteosarcoma of the spine: Experience of the Cooperative Osteosarcoma Study Group. Cancer 94: 1069-1077, 2002.

19. Mohamad O, Imai R, Kamada T, Nitta Y and Araki N; Working Group for Bone and Soft Tissue Sarcoma: Carbon ion radiotherapy for inoperable pediatric osteosarcoma. Oncotarget 9: 22976-22985, 2018. 
20. Matsunobu A, Imai R, Kamada T, Imaizumi T, Tsuji H, Tsujii H, Shioyama Y, Honda H and Tatezaki S; Working Group for Bone and Soft Tissue Sarcomas: Impact of carbon ion radiotherapy for unresectable osteosarcoma of the trunk. Cancer 118: 4555-4563, 2012.

21. Delaney G, Jacob S, Featherstone C and Barton M: The role of radiotherapy in cancer treatment: Estimating optimal utilization from a review of evidence-based clinical guidelines. Cancer 104 $1129-1137,2005$

22. Schwarz R, Bruland O, Cassoni A, Schomberg P and Bielack S: The role of radiotherapy in oseosarcoma. Cancer Treat Res 152 147-164, 2009.

23. Wu D, Chen K, Bai Y, Zhu X, Chen Z, Wang C, Zhao Y and Li M: Screening of diagnostic markers for osteosarcoma. Mol Med Rep 10: 2415-2420, 2014.

24. Engert F, Kovac M, Baumhoer D, Nathrath M and Fulda S: Osteosarcoma cells with genetic signatures of BRCAness are susceptible to the PARP inhibitor talazoparib alone or in combination with chemotherapeutics. Oncotarget 8: 48794-48806, 2017.

25. Li B and Ye Z: Epigenetic alterations in osteosarcoma: Promising targets. Mol Biol Rep 41: 3303-3315, 2014.

26. Turner N, Tutt A and Ashworth A: Hallmarks of 'BRCAness' in sporadic cancers. Nat Rev Cancer 4: 814-819, 2004.

27. Lord CJ and Ashworth A: BRCAness revisited. Nat Rev Cancer 16: 110-120, 2016

28. Lee JA, Paik EK, Seo J, Kim DH, Lim JS, Yoo JY and Kim MS Radiotherapy and gemcitabine-docetaxel chemotherapy in children and adolescents with unresectable recurrent or refractory osteosarcoma. Jpn J Clin Oncol 46: 138-143, 2016.

29. Dinçbaş FO, Koca S, Mandel NM, Hiz M, Dervişoğlu S, Seçmezacar H, Oksüz DC, Ceylaner B and Uzel B: The role of preoperative radiotherapy in nonmetastatic high-grade osteosarcoma of the extremities for limb-sparing surgery. Int J Radiat Oncol Biol Phys 62: 820-828, 2005.

30. Livak KJ and Schmittgen TD: Analysis of relative gene expression data using real-time quantitative PCR and the 2(-Delta Delta C(T)) method. Methods 25: 402-408, 2001

31. Marín A, Martín M, Liñán O, Alvarenga F, López $M$, Fernández L, Büchser D and Cerezo L: Bystander effects and radiotherapy. Rep Pract Oncol Radiother 20: 12-21, 2014.

32. Lewanski CR and Gullick WJ: Radiotherapy and cellular signalling. Lancet Oncol 2: 366-370, 2001.

33. Wang D and Lippard SJ: Cellular processing of platinum anticancer drugs. Nat Rev Drug Discov 4: 307-320, 2005.

34. Muggia F: Platinum compounds 30 years after the introduction of cisplatin: Implications for the treatment of ovarian cancer. Gynecol Oncol 112: 275-281, 2009.

35. Marcu L, van Doorn T and Olver I: Cisplatin and radiotherapy in the treatment of locally advanced head and neck cancer-a review of their cooperation. Acta Oncol 42: 315-325, 2003.

36. Petrelli F, De Stefani A, Raspagliesi F, Lorusso D and Barni S: Radiotherapy with concurrent cisplatin-based doublet or weekly cisplatin for cervical cancer: A systematic review and meta-analysis. Gynecol Oncol 134: 166-171, 2014.

37. Jacinto JK, Co J, Mejia MB and Regala EE: The evidence on effectiveness of weekly vs triweekly cisplatin concurrent with radiotherapy in locally advanced head and neck squamous cell carcinoma (HNSCC): A systematic review and meta-analysis. Br J Radiol 90: 20170442, 2017.

38. Zhong Q, Chen CF, Li S, Chen Y, Wang CC, Xiao J, Chen PL, Sharp ZD and Lee WH: Association of BRCA1 with the hRad50-hMre11-p95 complex and the DNA damage response. Science 285: 747-750, 1999.
39. Caestecker KW and Van de Walle GR: The role of BRCA1 in DNA double-strand repair: Past and present. Exp Cell Res 319: 575-587, 2013.

40. Zhang J and Powell SN: The role of the BRCA1 tumor suppressor in DNA double-strand break repair. Mol Cancer Res 3: 531-539, 2005.

41. SongH,CicekMS,DicksE,HarringtonP,RamusSJ,CunninghamJM, Fridley BL, Tyrer JP, Alsop J, Jimenez-Linan M, et al: The contribution of deleterious germline mutations in BRCA1, BRCA2 and the mismatch repair genes to ovarian cancer in the population. Hum Mol Genet 23: 4703-4709, 2014

42. Ramus SJ and Gayther SA: The contribution of BRCA1 and BRCA2 to ovarian cancer. Mol Oncol 3: 138-150, 2009.

43. Ratanaphan A: A DNA repair BRCA1 estrogen receptor and targeted therapy in breast cancer. Int J Mol Sci 13: 14898-14916, 2012.

44. Chechlinska M and Nowak R: The sensitivity of BRCA1 mutation carriers to ionising radiation: Questions of methodology. Breast Cancer Res Treat 115: 433, 2009.

45. Shi M, Ma F, Liu J, Xing H, Zhu H, Yu J and Yang M: A functional BRCA1 coding sequence genetic variant contributes to prognosis of triple-negative breast cancer, especially after radiotherapy. Breast Cancer Res Treat 166: 109-116, 2017.

46. Hallam S, Govindarajulu S, Huckett B and Bahl A: BRCA1/2 mutation-associated breast cancer, wide local excision and radiotherapy or unilateral mastectomy: A systematic review. Clin Oncol (R Coll Radiol) 27: 527-535, 2015.

47. Flórez MM, Fêo HB, da Silva GN, Yamatogi RS, Aguiar AJ, Araújo JP Jr and Rocha NS: Cell cycle kinetics, apoptosis rates and gene expressions of MDR-1, TP53, BCL-2 and BAX in transmissible venereal tumour cells and their association with therapy response. Vet Comp Oncol 15: 793-807, 2017.

48. Zheng Q, Wang B, Gao J, Xin N, Wang W, Song X, Shao Y and Zhao C: CD155 knockdown promotes apoptosis via AKT/Bcl-2/Bax in colon cancer cells. J Cell Mol Med 22: 131-140, 2018.

49. Fokkema E, De Vries EG, Groen HJ, Meijer C and Timens W: Expression of apoptosis-related proteins and morphological changes in a rat tumor model of human small cell lung cancer prior to and after treatment with radiotherapy, carboplatin, or combined treatment. Virchows Arch 442: 349-355, 2003.

50. Miyazaki T, Kato H, Faried A, Sohda M, Nakajima M, Fukai Y, Masuda N, Manda R, Fukuchi M, Ojima H, et al: Predictors of response to chemo-radiotherapy and radiotherapy for esophageal squamous cell carcinoma. Anticancer Res 25: 2749-2755, 2005.

51. Jeong SH, Jung JH, Han JH, Kim JH, Choi YW, Lee HW, Kang SY, Hwang YH, Ahn MS, Choi JH, et al: Expression of Bcl-2 predicts outcome in locally advanced non-small cell lung cancer patients treated with cisplatin-based concurrent chemoradiotherapy. Lung Cancer 68: 288-294, 2010.

52. Hassan C, Afshinnekoo E, Li S, Wu S and Mason CE: Genetic and epigenetic heterogeneity and the impact on cancer relapse. Exp Hematol 54: 26-30, 2017.

53. Gentric G, Mieulet V and Mechta-Grigoriou F: Heterogeneity in cancer metabolism: New concepts in an old field. Antioxid Redox Signal 26: 462-485, 2017.

54. Dagogo-Jack I and Shaw AT: Tumour heterogeneity and resistance to cancer therapies. Nat Rev Clin Oncol 15: 81-94, 2018.

This work is licensed under a Creative Commons Attribution-NonCommercial-NoDerivatives 4.0 International (CC BY-NC-ND 4.0) License. 